\title{
Spontaneous sister chromatid exchanges in mitotic chromosomes of cattle (Bos taurus L)
}

\author{
D Di Berardino ${ }^{1}, \mathrm{MB}$ Lioi $^{2}, \mathrm{MR}$ Scarfi ${ }^{3}$, \\ $\mathrm{V}_{\text {Jovino }}{ }^{1}, \mathrm{P}$ Marigliano ${ }^{1}$ \\ ${ }^{1}$ University of Naples 'Federico II', Department of Animal Science, \\ 80055 Portici, Naples; \\ ${ }^{2}$ University of Basilicata, Department of Animal Science, 85100 Potenza; \\ ${ }^{3}$ CNR-IRECE, 80124 Naples, Italy
}

(Received 9 September 1994; accepted 12 May 1995)

\begin{abstract}
Summary - Peripheral blood lymphocytes from 4 cattle donors were grown for 2 cell cycles in the presence of $0.1,0.25,0.5,1.0,2.5$ and $5.0 \mu \mathrm{g} / \mathrm{ml}$ of 5 -bromodeoxyuridine in order to detect the spontaneous level of sister chromatid exchanges and the dose-response relationships at low bromodeoxyuridine levels. Sister chromatid exchanges were counted on 50 s cycle metaphase spreads, randomly scored, for each donor at each dose. The mean rate of sister chromatid exchanges/cell at $0.1 \mu \mathrm{g} / \mathrm{ml}$ of BUdR was $2.48 \pm 1.75$, which can be considered as spontaneous. The dose-response curve increased more rapidly from 0.1 to $0.5 \mu \mathrm{g} / \mathrm{ml}$ of bromodeoxyuridine and less rapidly at higher concentrations. The frequency distribution of sister chromatid exchanges/cell and that of chromosomes showing various numbers of exchanges followed the Poisson probability function only within the range of 0.1 to $1.0 \mu \mathrm{g} / \mathrm{ml}$ of bromodeoxyuridine. The usefulness of determining the spontaneous level of sister chromatid exchanges in domestic animals is discussed in relation to its possible application for selection programs.
\end{abstract}

spontaneous sister chromatid exchange / SCE / lymphocyte culture / cattle

Résumé - Estimation des échanges interchromatidiques spontanés dans les chromosomes mitotiques de bovin (Bos taurus L). Des cultures de lymphocytes obtenus à partir du sang périphérique de 4 donneurs bovins ont été réalisées pendant 2 cycles cellulaires. Ces cultures sont effectuées en présence de 0,10, 0,25, 0,50, 1,0,2,5 et $5,0 \mu \mathrm{g} / \mathrm{ml}$ de bromodéoxyuridine (BrdU). Nous avons étudié les relations réponse (échanges chromatidiques)- dose de BrdU afin, notamment, de connaître le niveau spontané des échanges chromatidiques chez cette espèce. Ces échanges ont été comptés sur 50 plaques en métaphase II (par donneur et par dose) choisis par hasard. Le taux moyen d'échanges interchromatidiques (SCE : sister chromatid exchanges) par cellule (rapport SCE/cellule) pour une concentration de $0,1 \mu \mathrm{g} / \mathrm{ml}$ de $\mathrm{BrdU}$ est de 2,48, valeur pouvant être considérée comme le niveau spontané des échanges. La courbe réponse-dose de BrdU présente une 
rapide augmentation entre 0,10 et $0,50 \mu \mathrm{g} / \mathrm{ml}$ de $\mathrm{BrdU}$. Elle est plus rapide que pour des concentrations en BrdU plus élevées. Les distributions de fréquence des SCE et des chromosomes portant un nombre variable d'échanges suivent une loi de Poisson seulement pour des concentrations de BrdU de 0,10 à 1,00 $\mu \mathrm{g} / \mathrm{ml}$. L'utilité de déterminer le niveau spontané des échanges chromosomiques chez les animaux domestiques, pour une application possible aux programmes de sélection, est discutée.

échange interchromatidique spontané / culture de lymphocytes / bovin

\section{INTRODUCTION}

Spontaneous sister chromatid exchanges (SCEs) were first demonstrated by Kato (1974) and Wolff and Perry (1974) in Chinese hamster cell lines. Subsequently, other authors have extended these studies in in vitro (Tice et al, 1976) and in vitro systems (Mazrimas and Stetka, 1978; Tsuji and Kato, 1981; Morgan et al, 1986).

It is now well established that spontaneous SCEs occur as an integral part of DNA replication, even in the absence of agents known to induce SCEs (Tucker et al, 1986), and data are available for several species, including man, and various cell lines.

In domestic animals, SCEs have been studied in several species of cattle (Di Berardino and Shoffner, 1979; McFee and Sherrill, 1979; Di Berardino et al, 1983; Iannuzzi et al, 1991a, b; Catalan et al, 1994) pigs and sheep (McFee and Sherrill, 1979), goats (Sanchez and Burguete, 1992; Di Meo et al, 1993) and river buffalo (Iannuzzi et al, 1988).

In the majority of these studies, bromodeoxyuridine (BUdR) was utilized at a final concentration of $10 \mu \mathrm{g} / \mathrm{ml}$. Since BUdR is itself an inducer of SCE (Latt, 1973; Kligerman et al, 1982), the mean rates of SCE/cell detected so far reflect mostly induced exchanges. At the moment, nothing is known about the proportion of spontaneous versus induced SCEs.

For this reason, we decided to re-examine the SCE data obtained in domestic animals by focusing our attention on the spontaneous yield of SCEs which also provides an indirect estimation of the BUdR-induced SCEs.

The present paper refers to the spontaneous rate of SCEs in cattle (Bos taurus $\mathrm{L}$ ).

\section{MATERIALS AND METHODS}

Peripheral blood samples were obtained from 4 (2 males and 2 females) clinically healthy, unrelated, cattle of the Italian Friesian breed nearly 6 months of age. From each animal, $0.5 \mathrm{ml}$ aliquots of whole blood $\left(3 \times 10^{6}\right.$ lymphocytes $)$ were added to each of 6 culture flasks containing $9.5 \mathrm{ml}$ of RPMI 1640 medium (Gibco, Dutch modification New York, USA) together with $1 \mathrm{ml}$ of fetal calf serum (Gibco), $0.1 \mathrm{ml}$ of L-glutamine, $30 \mu \mathrm{l}$ of antibiotic/antimycotic mixture (Gibco) and $0.1 \mathrm{ml}$ of Pokeweed mitogen (Gibco). All cultures were grown at $37.5^{\circ} \mathrm{C}$. After $36 \mathrm{~h}$ from initiation, BUdR (Sigma, Saint Louis, MO, USA) was added to each culture flask at final concentrations of $0.1,0.25,0.5,1.0,2.5$ and $5.0 \mu \mathrm{g} / \mathrm{ml}$, respectively. 
The cultures were protected from light and allowed to grow for an additional $36 \mathrm{~h}$. Colcemid was added for the final $2 \mathrm{~h}$. Harvested cells were treated with hypotonic solution $\left(\mathrm{KCl}, 0.075 \mathrm{M}\right.$ ) for $20 \mathrm{~min}$ at $37.5^{\circ} \mathrm{C}$ and fixed 3 times with methanol/acetic acid solution (3:1). Air-dried slides were stained with a $0.2 \%$ acridine orange solution in phosphate buffer $(\mathrm{pH} 7.0)$ for $10 \mathrm{~min}$, washed thoroughly in tap water, mounted in phosphate buffer and sealed with paraffin. SCEs were counted on $50 \mathrm{~s}$ cycle metaphase spreads, randomly scored for each animal, for each BUdR level. To avoid possible individual bias, all scoring was performed by the same person. In our experimental conditions it was not possible to utilize BUdR doses lower than $0.1 \mu \mathrm{g} / \mathrm{ml}$ because of the poorly defined sister chromatid differential.

\section{RESULTS}

Table I reports mean number and standard deviation of the SCEs per cell scored at each BUdR level in the 4 animals tested. At the lowest dose of $0.1 \mu \mathrm{g} / \mathrm{ml}$ of BUdR the individual SCE/cell rates varied from $1.64 \pm 1.16$ to $3.62 \pm 2.1$, with an average of $2.48 \pm 1.75$. At the dose of $5.0 \mu \mathrm{g} / \mathrm{ml}$ of BUdR, the individual SCE/cell rates varied from $3.64 \pm 1.9$ to $6.58 \pm 3.05$, with an average of $5.16 \pm 2.75$. The analysis of variance performed on these data indicated significant differences at each BUdR level $(P<0.001)$ among the 4 animals investigated.

Table I. Sister chromatid exchanges in bovine lymphocytes exposed to varying concentrations of $\mathrm{BUdR}^{\mathrm{a}}$.

\begin{tabular}{lcccccc}
\hline Donor & \multicolumn{6}{c}{ BUdR concentration $(\mu \mathrm{g} / \mathrm{ml}$ of culture medium) } \\
\cline { 2 - 7 } & 0.1 & 0.25 & 0.5 & 1.0 & 2.5 & 5.0 \\
\hline 1 & $1.64 \pm 1.16$ & $2.24 \pm 1.38$ & $3.74 \pm 1.66$ & $4.26 \pm 2.18$ & $6.92 \pm 3.34$ & $6.58 \pm 3.0$ \\
2 & $2.40 \pm 1.40$ & $4.60 \pm 2.41$ & $4.80 \pm 2.36$ & $4.84 \pm 2.25$ & $5.52 \pm 2.54$ & $6.18 \pm 2.27$ \\
3 & $2.26 \pm 1.64$ & $2.40 \pm 1.46$ & $2.54 \pm 1.33$ & $2.84 \pm 1.36$ & $3.14 \pm 2.09$ & $3.64 \pm 1.90$ \\
4 & $3.62 \pm 2.10$ & $2.56 \pm 1.66$ & $3.22 \pm 2.10$ & $3.76 \pm 1.88$ & $3.54 \pm 2.11$ & $4.24 \pm 2.54$ \\
$1-4$ & $2.48 \pm 1.75$ & $2.95 \pm 2.00$ & $3.58 \pm 2.06$ & $3.93 \pm 2.07$ & $4.78 \pm 2.75$ & $5.16 \pm 2.75$ \\
\hline
\end{tabular}

${ }^{\mathrm{a}}$ Each entry is the mean $\pm \mathrm{SE}$ for 50 metaphase cells.

Figure 1 shows the mean rate of SCE/cell in the 4 donors tested. The overall mean rate of SCE/cell increased more rapidly between 0.1 and $0.5 \mu \mathrm{g} / \mathrm{ml}$ of BUdR and less rapidly at further concentrations, thus indicating a saturation level. This trend was found to be logistic $\left(y=a / 1+e^{b x}\right.$, where $a=5.05$ and $\left.b=-1.31\right)$.

When the data were examined by using quartile statistics (fig 2), $50 \%$ of the $\mathrm{SCE} /$ cell values observed between 0.1 (D1) and 0.25 (D2) $\mu \mathrm{g} / \mathrm{ml}$ of BUdR remained fairly stable, starting to rise at higher concentrations. This would suggest that (in our laboratory conditions) up to $0.25 \mu \mathrm{g} / \mathrm{ml}$ of BUdR the exchanges could be considered as spontaneous, being little affected by the analogue.

In order to characterize the distribution of the exchanges in the cell population, table II was prepared, in which the SCE/cell values of the 4 animals observed at various concentrations of $\mathrm{BUdR}$ were pooled and tested for fit to the Poisson 


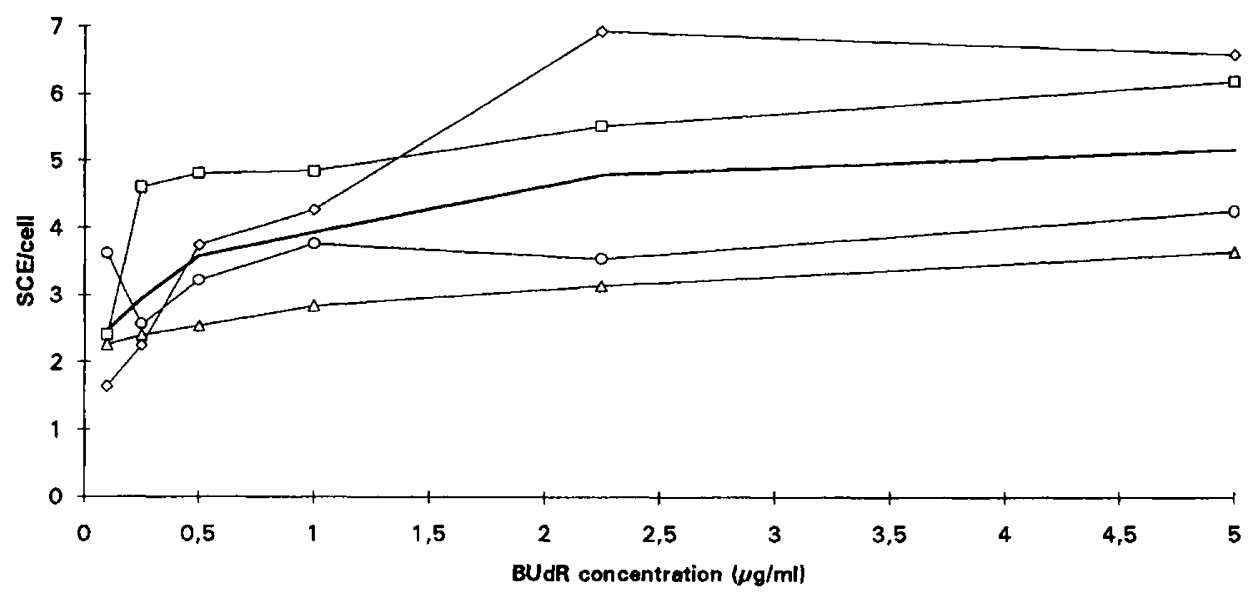

Fig 1. Mean rates of SCE/cell in cattle peripheral lymphocytes exposed to increasing doses of BUdR. The solid line is the overall mean of 200 cells (50 cells, 4 donors) at each BUdR dose. $\longrightarrow$ donor $1 ;-\square$ donor 2 ; $\longrightarrow-$ donor 3 ; $\longrightarrow$ donor 4 ; mean.

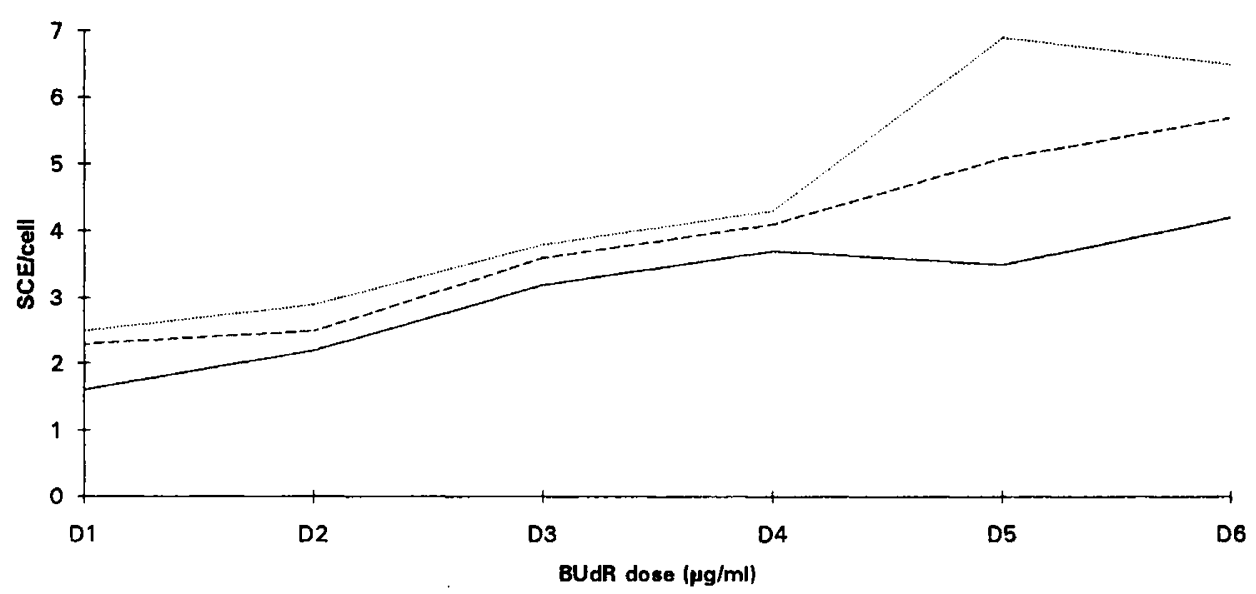

Fig 2. Evolution of the 'quartiles' at various BUdR concentrations. Notice that between 0.1 (D1) and $0.25(\mathrm{D} 2) \mu \mathrm{g} / \mathrm{ml}$ of $\mathrm{BUdR}$ the intermediate line, representing $50 \%$ of the SCE/cell values is nearly stable, being little affected by the increase of BUdR concentration. $25 \%$; - - - - 50\%; $75 \%$.

distribution. The chi-square analysis revealed that, at the $5 \%$ probability level, the expected frequencies were close to the observed only within the range of 0.1 to $1.0 \mu \mathrm{g} / \mathrm{ml}$ of BUdR, whereas at higher BUdR concentrations the observed distribution deviated significantly from the theoretical model. Such a deviation becomes particularly evident at the dose of $5.0 \mu \mathrm{g} / \mathrm{ml}$ of BUdR. Figure 3 shows the frequency distributions of the SCEs/cell observed at 0.1 (D1) and 5.0 (D2) 
$\mu \mathrm{g} / \mathrm{ml}$ of BUdR and the Poisson expected frequencies. It is quite evident that in D6 the Poisson expectations do not fit the observed frequencies $\left(\chi^{2}=30.2>\chi_{0.05}^{2}\right)$. However, when 2 subpopulations of lymphocytes are considered instead of 1 (Exp. D6a line), the Poisson distribution fits well the observed frequencies, with a chisquare of $13.33\left(\chi_{0.05}^{2}=18.3 ; d f=10\right)$.

Table II. Distribution of the observed and Poisson frequencies of SCEs/cell in bovine lymphocytes exposed to varying concentrations of $B U d R^{\mathrm{a}}$.

\begin{tabular}{|c|c|c|c|c|c|c|c|c|c|c|c|c|}
\hline \multirow[t]{3}{*}{$S C E /$ cell } & \multicolumn{12}{|c|}{$B U d R$ concentration $(\mu \mathrm{g} / \mathrm{ml}$ of culture medium) } \\
\hline & \multicolumn{2}{|c|}{0.10} & \multicolumn{2}{|c|}{0.25} & \multicolumn{2}{|c|}{0.50} & \multicolumn{2}{|c|}{1.0} & \multicolumn{2}{|c|}{2.5} & \multicolumn{2}{|c|}{5.0} \\
\hline & Obs & $\operatorname{Exp}$ & Obs & Exp & Obs & Exp & Obs & $\operatorname{Exp}$ & Obs & $\operatorname{Exp}$ & Obs & $\operatorname{Exp}$ \\
\hline 0 & 23 & 16.7 & 9 & 10.5 & & & & & & & & \\
\hline 1 & 39 & 41.5 & 39 & 30.9 & 38 & 25.7 & 15 & 19.4 & 16 & 9.7 & 16 & 7.1 \\
\hline 2 & 49 & 51.5 & 49 & 45.5 & 30 & 35.7 & 34 & 30.3 & 24 & 19.2 & 16 & 15.3 \\
\hline 3 & 42 & 42.6 & 43 & 44.8 & 32 & 42.6 & 48 & 39.7 & 30 & 30.6 & 34 & 26.3 \\
\hline 4 & 24 & 26.4 & 22 & 33 & 41 & 38.2 & 33 & 39.1 & 38 & 36.5 & 19 & 33.9 \\
\hline 5 & 11 & 13.1 & 18 & 19.5 & 27 & 27.3 & 37 & 30.7 & 27 & 34.9 & 33 & 35.0 \\
\hline 6 & 6 & 5.4 & 8 & 9.5 & 18 & 16.3 & 11 & 20.1 & 18 & 27.8 & 24 & 30.1 \\
\hline 7 & 6 & 2.7 & 6 & 4 & 6 & 8.3 & 9 & 11.3 & 18 & 19 & 16 & 22.2 \\
\hline$>8$ & & & 6 & 2.1 & 8 & 5.8 & 5 & 5.5 & 8 & 11.4 & 16 & 14.3 \\
\hline$>9$ & & & & & & & 8 & 3.9 & 11 & 6 & 14 & 8.2 \\
\hline$>10$ & & & & & & & & & & 4.9 & 6 & 4.2 \\
\hline$>11$ & & & & & & & & & & & 6 & 3.3 \\
\hline$d f$ & 7 & 7 & & & 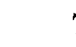 & & $\varepsilon$ & & 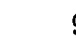 & 9 & 10 & \\
\hline$\chi^{2}$ & & .2 & & 1.4 & & .3 & 14 & .3 & & 1.1 & 30 & .2 \\
\hline$P 5 \%$ & 14 & 1.1 & & .5 & & .1 & 15 & .5 & & 5.9 & 18 & 3 \\
\hline$P 1 \%$ & 18 & 3.5 & & .1 & & .5 & 20 & .1 & & 1.7 & 23 & .2 \\
\hline$P 1 \%$ & 24 & 1.3 & & .1 & & .3 & 26 & .1 & & 7.9 & 29 & .6 \\
\hline
\end{tabular}

${ }^{a}$ For each BUdR level, 200 metaphases are considered. Obs = number of cells observed; Exp $=$ number of cells expected.

Table III reports the overall number of chromosomes with 0,1 and 2 or more exchanges at each BUdR level and the number expected on the basis of the Poisson distribution. The chi-square analysis revealed that from 0.1 to $1.0 \mu \mathrm{g} / \mathrm{ml}$ of BUdR the expected frequencies were close $(P<0.05)$ to the observed, whereas at higher concentrations they were not, thus confirming to a large extent that low BUdR levels provide a better fit to the Poisson expectations, as previously suggested by Tucker et al (1986).

\section{DISCUSSION}

Spontaneous SCEs provide an indication of the extent of somatic recombination occurring in untreated cells and allow estimation of the proportion of induced SCEs (Tucker et al, 1986). Detection of the spontaneous level of SCEs in cattle 


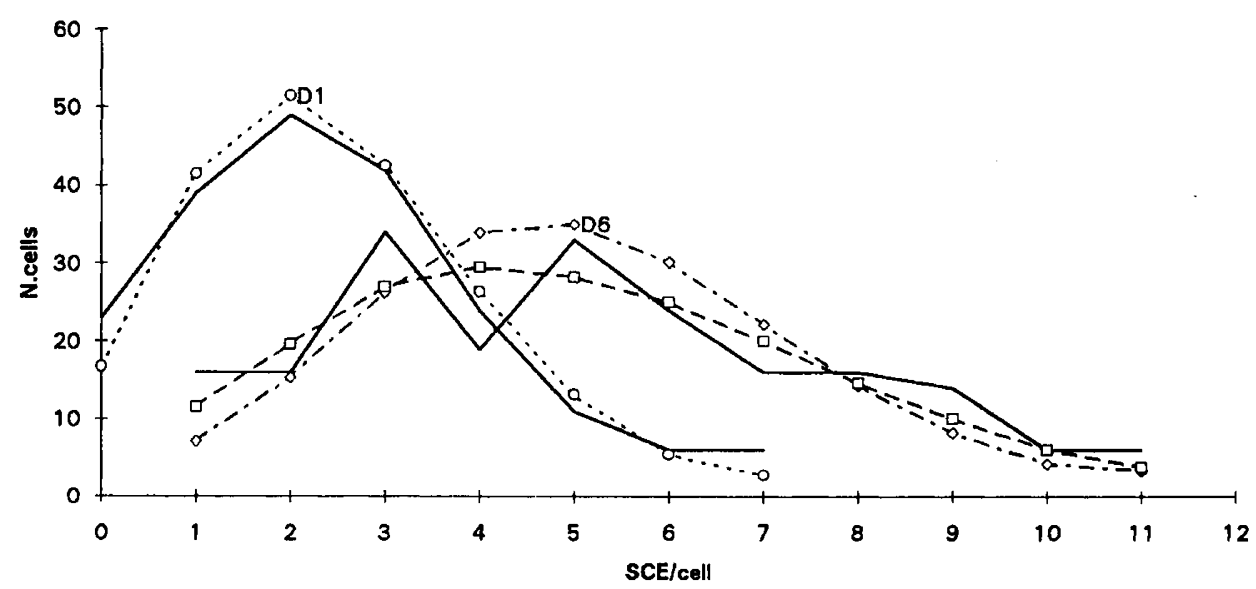

Fig 3. Observed and 'Poisson' expected frequencies of SCE/cell at 0.1 (D1) and 5.0 (D6) $\mu \mathrm{g} / \mathrm{ml}$ of BUdR. The D6a line represents the Poisson distribution by considering 2 subpopulations of lymphocytes instead of 1. - Obs D1; - -o- - Exp D1; Obs; - $\diamond--\operatorname{Exp}$ D6; - - - Exp D6a.

Table III. Comparison of observed distribution of SCEs with Poisson expectations at varying BUdR levels.

\begin{tabular}{|c|c|c|c|c|c|}
\hline \multicolumn{2}{|c|}{$B U d R /$ dose } & \multicolumn{3}{|c|}{$\begin{array}{l}\text { Number of chromosomes with } \\
\text { indicated number of exchanges }\end{array}$} & \multirow[t]{2}{*}{ Statistics } \\
\hline & & 0 & 1 & $>2$ & \\
\hline \multirow[t]{2}{*}{0.1} & Obs & 11522 & 462 & 16 & $\gamma=0.041$ \\
\hline & $\operatorname{Exp}$ & 11518 & 472 & 10 & $\chi^{2}=3.811<\chi_{0.05}^{2}$ \\
\hline \multirow[t]{2}{*}{0.25} & Obs & 11432 & 546 & 22 & $\gamma=0.049$ \\
\hline & $\operatorname{Exp}$ & 11426 & 560 & 14 & $\gamma^{2}=4.924<\chi_{0.05}^{2}$ \\
\hline \multirow[t]{2}{*}{0.5} & Obs & 11315 & 656 & 29 & $\gamma=0.060$ \\
\hline & Exp & 11302 & 678 & 20 & $\chi^{2}=4.78<\chi_{0.05}^{2}$ \\
\hline \multirow[t]{2}{*}{1.0} & Obs & 11250 & 715 & 35 & $\gamma=0.065$ \\
\hline & Exp & 11245 & 731 & 24 & $\chi^{2}=5.393<\chi_{0.05}^{2}$ \\
\hline \multirow[t]{2}{*}{2.5} & Obs & 11092 & 858 & 50 & $\gamma=0.080$ \\
\hline & Exp & 11078 & 886 & 36 & $\chi^{2}=6.346>\chi_{0.05}^{2}$ \\
\hline \multirow[t]{2}{*}{5.0} & Obs & 11034 & 901 & 65 & $\gamma=0.086$ \\
\hline & Exp & 11011 & 947 & 42 & $\chi^{2}=14.877>\chi_{0.05}^{2}$ \\
\hline
\end{tabular}

has never been attempted. The only report available is that of McFee and Sherrill (1979) who detected a mean value of $5.95 \mathrm{SCE} /$ cell in cattle lymphocytes exposed to $0.5 \mu \mathrm{g} / \mathrm{ml}$ of BUdR. The present paper reports a mean value of $2.48 \mathrm{SCEs} /$ cell at a concentration of $0.1 \mu \mathrm{g} / \mathrm{ml}$ of BUdR. Below this level, sister chromatid differential 
was not satisfactory for SCE detection. Even though BUdR concentrations less than $0.1 \mu \mathrm{g} / \mathrm{ml}$ could be used in other laboratory conditions (Tucker et al, 1986), the mean value of $2.48 \mathrm{SCEs} /$ cell can be considered very close to the spontaneous yield of SCEs in cattle. Since the exchange frequency observed is the sum of exchanges formed during 2 subsequent cell cycles, the average frequency of SCEs per cell generation is 1.24. By considering that cattle somatic cells have a diploid number of 60 and a diploid DNA content of $6.4 \mathrm{pg}$ (Green and Bahr, 1975), the corresponding values are 0.02 SCEs per chromosome per cell generation and 0.19 SCEs per picogram of DNA.

The spontaneous yield of $2.48 \mathrm{SCEs} /$ cell in cattle chromosomes is very close to that reported by Kato (1974) in a pseudodiploid Chinese hamster cell line exposed to the same BUdR concentration (2.3 SCEs/cell) but considerably lower than that reported by Tucker et al (1986) in human and mouse blood lymphocytes exposed to $30 \mathrm{nM}$ of BUdR (7.2 and 4.9 SCEs/cell, respectively). McFee and Sherrill (1979) also reported higher values of SCEs/cell in cattle, pig, sheep and human lymphocytes but they used $0.5 \mu \mathrm{g} / \mathrm{ml}$ of BUdR. The dose-response curve of cattle chromosomes exposed to increasing doses of BUdR was found to be logistic. The yield of SCEs rises quite steeply between 0.1 and $1.0 \mu \mathrm{g} / \mathrm{ml}$ of $\mathrm{BUdR}$. Above this concentration the curve rises slowly, indicating a saturation level. This pattern is very similar to that found by Wolff and Perry (1974) in Chinese hamster ovary cells grown under BUdR concentrations varying from 0.25 to $20 \mu \mathrm{g} / \mathrm{ml}$, and also to that reported by McFee and Sherrill (1979) on cattle lymphocytes grown at concentrations varying from 0.5 to $20 \mu \mathrm{g} / \mathrm{ml}$ of $\mathrm{BUdR}$.

However, a different pattern of the dose-response curve has been reported by other authors who found a plateau of the SCE frequencies at low BUdR doses in a Chinese hamster pseudodiploid cell line (Kato, 1974), in an in vivo rat system (Tice et al, 1976), in HeLa cells (Tsuji and Kato, 1981), and in human and mouse lymphocytes (Tucker et al, 1986). These contradictory results can be accounted for by a variety of factors such as species, individuals, cell source and laboratory conditions (Das and Sharma, 1983). However, when quartile statistics were applied to our data, a fairly steady line was found between 0.1 and $0.25 \mu \mathrm{g} / \mathrm{ml}$ of BUdR, thus indicating that $50 \%$ of the cells scored were little affected in their SCE response by the increase of BUdR. Furthermore, when the data reported in table I are examined within the range from 0.1 to $1.0 \mu \mathrm{g} / \mathrm{ml}$ of BUdR, donors $\mathrm{n} 3$ and $\mathrm{n} 4 \mathrm{show}$ a plateau of SCE values, while donors $n 1$ and $n 2$ display a rapid increase of SCE/cell frequencies. This finding indicates that individual variations play an important role in determining the overall dose-response pattern. Our data also indicate that when Pokeweed is used as mitogen for SCE studies, BUdR concentrations higher than $1.0 \mu \mathrm{g} / \mathrm{ml}$ may provide SCE responses which do not follow Poisson expectations, due to the presence of 2 subpopulations of $B$ and $T$ lymphocytes which are known to differ in their SCE response, proliferation rate and sensitivity to chemically induced damage (Lindblad and Lambert, 1981; Erexson et al, 1983; Bloom et al, 1993). Recently, Catalan et al (1994) studied a group of 24 cattle of different breeds, ages and farms, and reported a spontaneous incidence of $5.77 \pm 0.082$ (se) SCEs by using $5 \mu \mathrm{g} / \mathrm{ml}$ of BUdR. While this value is in close agreement with ours $(5.16 \pm 2.75$ (sd) SCEs/cell), we can hardly believe that SCEs obtained at $5 \mu \mathrm{g} / \mathrm{ml}$ of BUdR can be considered as spontaneous, as claimed by those authors. 
The results of the present investigation demonstrated that in cattle the mean rates of SCE/cell reported by various authors so far include a spontaneous level of 2.5 SCEs/cell, the remaining SCEs being induced by BUdR.

The SCE test is commonly used to assess chromosome instability (Chaganti et al, 1974) and genetic damage under mutagenic exposure (Carrano et al, 1978). Spontaneous SCEs have been related to the 'unscheduled' DNA synthesis occurring in mammalian cells to repair apurinic DNA sites (Verly et al, 1973; Kato, 1974). Even though the molecular mechanism of SCE formation still remains to be elucidated, both types of SCEs seem to be related to the DNA repair activity of the cells. It seems, therefore, important to ascertain the proportion of spontaneous versus induced SCEs, rather than the overall SCE response alone. Variations among species, breeds, and individuals in the proportion of spontaneous/induced SCEs would reflect different DNA repairing efficiencies which should be taken into consideration when breeding animals, especially those destined for artificial insemination, are evaluated and selected for animal production improvement. This aspect, however, is worthy of further investigation.

\section{ACKNOWLEDGMENTS}

Special thanks are given to C Vitale of the Department of Statistics, University of Salerno, for his valuable collaboration in the statistical analysis. This research was supported by the National Research Council of Italy, Special Project Raisa, sub-project No 3 Paper No 2234 .

\section{REFERENCES}

Bloom SE, Potchinnsky MB, Lorr NA, Muscarella DE (1993) Cytogenetic mechanisms in the selective toxicity of mitomycin C towards B-lymphocytes compared to $\mathrm{T}$ lymphocytes in vivo and in vitro. Proc 8th North Amer Coll Cytogenet Dom Anim and Gene mapping, July, 13-16, University of Guelph, Guelph, ON, Canada, 25-27

Carrano AV, Thompson LH, Lindl PA, Minkler JL (1978) Sister chromatid exchange as an indicator of mutagenesis, Nature (Lond) 271, 551-553

Catalan J, Moreno C, Arruga MV (1994) Distribution and sources of variability of sister chromatid exchange frequencies in cattle. Genet Sel Evol, 26, 3-14

Chaganti RSK, Schonberg S, German J (1974) A many-fold increase in sister chromatid exchanges in Bloom's syndrome lymphocytes. Proc Natl Acad Sci USA 71, 4508-4512

Das BC, Sharma T (1983) Reduced frequency of baseline sister chromatid exchanges in lymphocytes grown in antibiotics and serum excluded culture medium. Hum Genet 64 , 249-253

Di Berardino D, Shoffner RN (1979) Sister chromatid exchange in chromosomes of cattle (Bos taurus L). J Dairy Sci 62, 627-632

Di Berardino D, Iannuzzi L, Freola A, Matassino D (1983) Chromosome instability in a newborn calf affected by congenital malformation. Vet Rec 112, 429-432

Di Meo GP, Iannuzzi L, Perucatti A, Ferrara L, Pizzillo M, Rubino R (1993) Sister chromatid exchange in the goat (Capra hircus $\mathrm{L}$ ). Hereditas 118, 35-38

Erexson GL, Wilnier JL, Klingerman AD (1983) Analyses of sister-chromatid exchange and cell-cycle kinetics in mouse T- and B-lymphocytes from peripheral blood cultures. Mutat Res 109, 271-281 
Green JR, Bahr GF (1975) Comparison of G, Q and EM banding patterns exhibited by chromosome complement of the Indian muntjac, Muntiacus muntjak, with reference to nuclear DNA content and chromatine ultrastructure. Chromosoma 50, 53-67

Iannuzzi L, Perucatti A, Di Meo GP, Ferrara L (1988) Sister chromatid exchange in chromosomes of river buffalo (Bubalus bubalis L). Caryologia 41, 237-244

Iannuzzi L, Di Meo GP, Perucatti A, Ferrara L, Gustavsson I (1991a) Sister chromatid exchange in chromosomes of cattle from three different breeds reared under similar conditions. Hereditas 114, 201-205

Iannuzzi L, Di Meo GP, Perucatti A, Ferrara L, Gustavsson I (1991b) Sister chromatid exchange in cattle marker chromosomes. Caryologia 44, 145-152

Kato H (1974) Spontaneous sister chromatid exchanges detected by a BrdU labelling method. Nature (Lond) 251, 70-72

Kligerman AD, Wilmer JL, Erexson GL (1982) Characterization of a rat lymphocyte culture system assessing sister chromatid exchanges. II. Effects of 5-bromodeoxyuridine concentration, number of white blood cells in inoculum, and inoculum volume. Environ Mutagen 4, 585-594

Latt SA (1973) Microfluorometric detection of deoxyribonucleic acid replication in human metaphase chromosomes. Proc Natl Acad Sci USA, 70, 3395-3399

Lindblad A, Lambert B (1981) Relation between sister chromatid exchange, cell proliferation and proportion of B and T cells in human lymphocyte cultures. Hum Genet 57, 31-34

Mazrimas JA, Stetka DG (1978) Direct evidence for the role of incorporated BUdR in the induction of sister chromatid exchanges. Exp Cell Res 117, 23-30

McFee AF, Sherrill MN (1979) Species variation in BrdUrd-induced sister chromatid exchanges. Mutat Res 62, 131-138

Morgan WF, Bodycote J, Doida Y, Fero ML, Hahn P, Kapp LN (1986) Spontaneous and 3-aminobenzamide-induced sister chromatid exchange frequencies estimated by ring chromosome analysis. Mutagenesis 1, 453-459

Sanchez C, Burguete I (1992) Sister chromatid exchange on the goat. Proc 10th Em Coll Cytogenet Dom Anim, August, 18-21, Utrecht University, Utrecht, the Netherlands, 218-222

Tice R, Chaillet J, Schneider EL (1976) Demonstration of spontaneous sister chromatid exchanges in vivo. Exp Cell Res 102, 426-429

Tsuji H, Kato H (1981) Three-way differential staining of sister chromatids in M3 chromosomes. Exp Cell Res 134, 433-444

Tucker JD, Christensen ML, Strout CL, Carrano AV (1986) Determination of the baseline sister chromatid exchange frequency in human and mouse peripheral lymphocytes using monoclonal antibodies and very low doses of bromodeoxyuridine. Cytogenet Cell Genet $43,38-42$

Wolff S, Perry P (1974) Differential Giemsa staining of sister chromatids and the study of sister chromatid exchanges without autoradiography. Chromosoma (Berl) 48, 341-353

Verly WG, Paquette Y, Thibodeau L (1973) Nuclease for DNA apurinic sites may be involved in the maintenance of DNA in normal cells. Nature New Biol 244, 67-69 